\title{
Premenstrual syndrome: the differences of symptomatic expression according to the cultures
}

Introduction. Premenstrual syndrome (PMS) currently represents the most common functional disorder. Its prevalence could reach up to $70 \%$ of women of childbearing age. It is apprehended as a complex psycho-neuro-endocrine disorder, of universal distribution, but variable in its frequency and symptomatic expression depending on the cultures [1].

Purposes. Describe the severity and symptomatic expression of premenstrual syndrome and identify cultural aspects among Tunisian women.

Materials and Methods. It is a cross-sectional study including 200 women : students and paramedical staff of childbearing age, who have given their consent. For the data collection, a general questionnaire and two validated scales were used : the short Premenstrual Assessment Form (sPAF) and the Menstrual Attitude Questionnaire (MAQ).

\section{Results}

\section{A- Severity of PMS}

- The prevalence of premenstrual syndrome was $85 \%$

The mean age was $28.65 \pm 0.6$ years

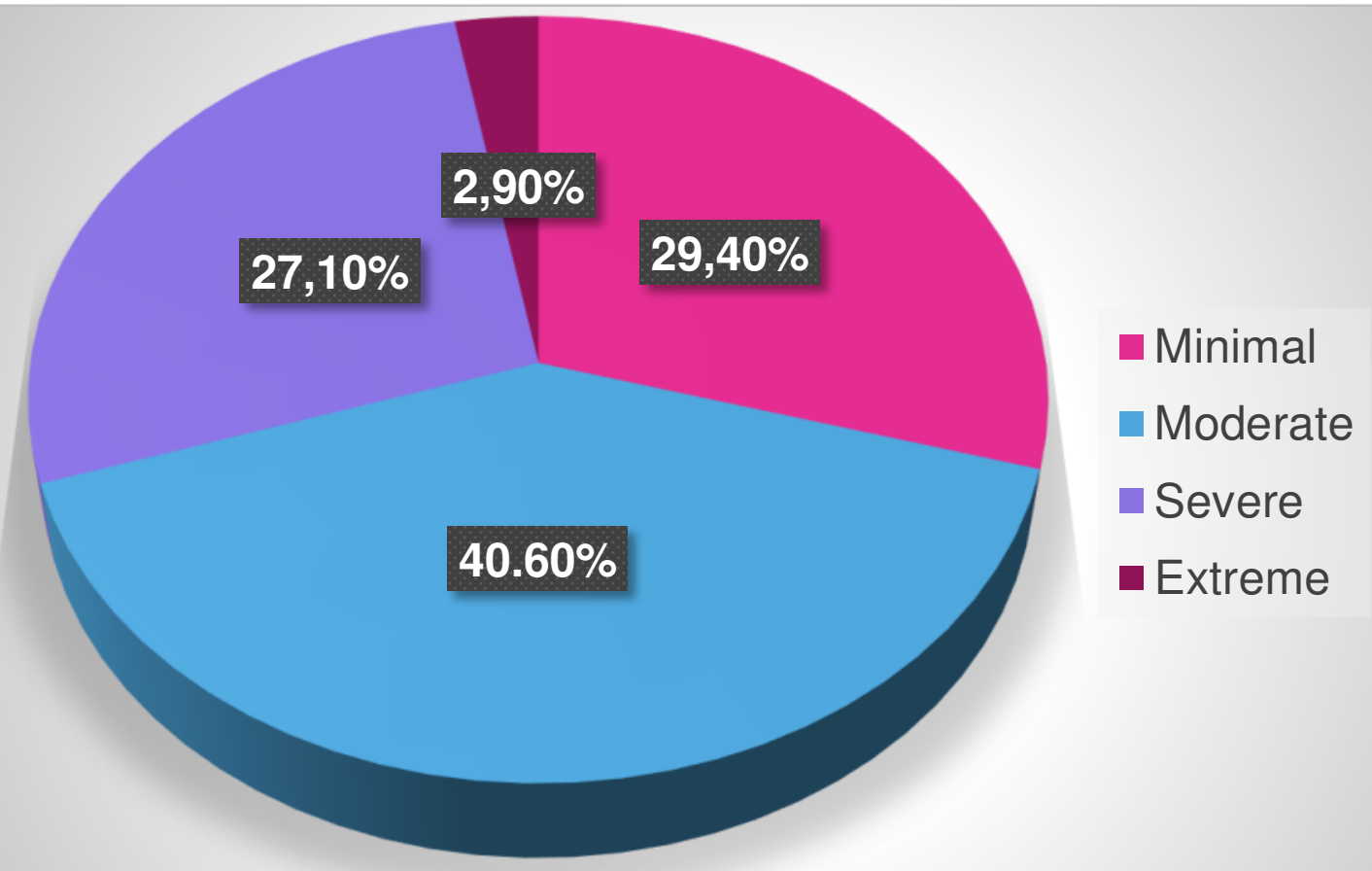

Fig. 1: Distribution according to the severity of the SPM evaluated by the PAF

\section{B- Symptomatic manifestations of PMS}

\begin{tabular}{|l|c|c|}
\hline \multicolumn{1}{|c|}{ Items } & Prevalence & Severity \\
\hline $\begin{array}{l}\text { Lumbar, muscular } \\
\text { and joint pain }\end{array}$ & $65.9 \%$ & $28.2 \%$ \\
\hline $\begin{array}{l}\text { Feeling of } \\
\text { permanent tension }\end{array}$ & $63.5 \%$ & $29.4 \%$ \\
\hline Irritability access & $61.8 \%$ & $28.2 \%$ \\
\hline $\begin{array}{l}\text { Annoyance or } \\
\text { abdominal pain }\end{array}$ & $59.4 \%$ & $23.5 \%$ \\
\hline $\begin{array}{l}\text { Breast pain and } \\
\text { swelling }\end{array}$ & $56.5 \%$ & $22.4 \%$ \\
\hline Sadness & $43.5 \%$ & $15.9 \%$ \\
\hline
\end{tabular}

\begin{tabular}{|l|c|c|l||}
\hline \multicolumn{1}{|c|}{ Authors } & Year & Country & \multicolumn{1}{|c|}{$\begin{array}{c}\text { The most common PMS } \\
\text { symptoms }\end{array}$} \\
\hline Our study & 2005 & Tunisia & $\begin{array}{l}\text { feeling of permanent tension, } \\
\text { irritability, lumbar, abdominal and } \\
\text { mastodynia. }\end{array}$ \\
\hline $\begin{array}{l}\text { Warner and } \\
\text { Bancroft [2] }\end{array}$ & 1990 & $\begin{array}{l}\text { United } \\
\text { Kingtom }\end{array}$ & $\begin{array}{l}\text { psychological symptoms > physical } \\
\text { symptoms }\end{array}$ \\
\hline Chang and al.[3] & 1995 & $\begin{array}{l}\text { Hong } \\
\text { Kong }\end{array}$ & Fatigue algia and negative affects \\
\hline $\begin{array}{l}\text { Shershah and al. } \\
\text { [4] }\end{array}$ & 1991 & Pakistan & Pain in lower abdomen, cramps \\
\hline $\begin{array}{l}\text { Cenac, Maikibi } \\
\text { and Develoux [5] }\end{array}$ & 1987 & Niger & $\begin{array}{l}\text { sore breasts, abdominal pain and } \\
\text { irritability }\end{array}$ \\
\hline $\begin{array}{l}\text { Montero and al. } \\
\text { [6] }\end{array}$ & 1999 & Maroc & premenstrual pain \\
\hline $\begin{array}{l}\text { Mchichi alami } \\
\text { and al.[7] }\end{array}$ & 2002 & Maroc & $\begin{array}{l}\text { lethargy and fatigue +++ mastalgia, } \\
\text { headache, arthralgia, weight gain++ } \\
\text { depressive mood +/-,dysomnias + / }\end{array}$ \\
\hline $\begin{array}{l}\text { Moawed [8] } \\
\text { cramps+++, lumbalgia ++, fatigue } \\
++, \text { chest pain +, and headaches + }\end{array}$ \\
\hline $\begin{array}{l}\text { Shye and Jaffe } \\
\text { [9] }\end{array}$ & 19991 & Israel & premenstrual pain +++ \\
\hline $\begin{array}{l}\text { Sinanovic and } \\
\text { al. [10] }\end{array}$ & 2003 & Bosnia & Physical> psychological symptoms \\
\hline $\begin{array}{l}\text { Bridou and al. } \\
\text { [11] }\end{array}$ & 2013 & France & $\begin{array}{l}\text { Bellyache ++, low back pain, } \\
\text { irritability, physical anhedonia }\end{array}$ \\
\hline
\end{tabular}

In Each culture, the affective symptomatology of PMS differs according to the nature and frequency of reported symptoms [1-9]. Premenstrual symptoms are more severe among cultured and active women. Urban ones [12]

this review, it is clear that the predominance of psychological This somatization is explained by psychoanalytic theories as a process of Elsewhere, culture plays an important role in shaping the meaning that menstrual blood is associated with fertility and prosperity, women experienced less premenstrual syndrome. activities. For some [14], in the Arab world, the body appears valued, as of social life, such as childbirth or menstruations. This investment of the body is reflected in particular by the frequency of aspects of somatization in

Conclusion. These findings highlight the symptomatic variability and the cultural significance and repercussions of the premenstrual syndrome and invite to implement a personalized approach in its evaluation, its prevention and its treatment. 